\title{
KINERJA RANTAI PASOK BUNGA POTONG DI KOTA DENPASAR
}

\section{Supply Chain Performance of Cut Flowers In Denpasar City}

\author{
Dice Fice Siska Ndoen*, Ketut Budi Susrusa, Made Sudarma
}

Program Studi Magister Agribisnis, Fakultas Pertanian, Universitas Udayana, Bali, Indonesia

*Email: dicefice@yahoo.com

\begin{abstract}
Activities related to international and national meetings in Bali require cut flowers and their arrangements as a means of decoration and so on. Bali only produces a few types of cut flowers so it is supplied by cut flowers from outside Bali. This study aims to analyze the performance of cut flower supply chains in Denpasar City. The study was conducted in Denpasar with a descriptive qualitative approach. Determination of respondents using the snowball method with a total of 53 people consisting of farmers, suppliers, distributors, retailers and cut flower consumers. The results showed that the four types of cut flowers that dominated the cut flower market in Denpasar were roses, chrysanthemums, peacock and savory night. There were four large distributors who distribute cut flowers to 76 retailers in Denpasar City. Cut flowers from regions in West Java and East Java are sent every day. When payment can be made in cash which is directly paid on the spot, with credit or by transfer using mobile banking. Supply chain performance can be seen from the farmer's share ranges from $30 \%$ - 45\% of the retailer's price. Which has the lowest share of farmer's share was nightly flowers (30\%) followed by roses (35\%) then pikok flowers (36\%) and the highest was chrysanthemums (45\%). Share prices at the supplier level ranges from $40 \%$ $65 \%$ of the retail price and at the distributor level ranges from 50\% - 80\% of the retail price. Revenue and cost ratios are dominated by retailers with a range between 4.71 - 10.76. Each member of the marketing agency performs different marketing functions depending on the needs including: product transportation, sorting and grading, packaging, packaing, transportation and distribution. Herewith the costs incurred have an impact on the prices received by end consumers. The concentration ratio (CR 4) at the retail level is 42.17 or belongs to a weak oligopoly market structure.
\end{abstract}

Keywords: Cut flowers, supply chain performance

\begin{abstract}
ABSTRAK
Kegiatan yang terkait dengan pertemuan internasional dan nasional di Bali membutuhkan bunga potong dan pengaturannya sebagai alat dekorasi dan sebagainya. Bali hanya menghasilkan beberapa jenis bunga potong sehingga dipasok oleh bunga potong dari luar Bali. Penelitian ini bertujuan untuk menganalisis kinerja rantai pasokan bunga potong di Kota Denpasar. Penelitian dilakukan di Denpasar dengan pendekatan kualitatif deskriptif. Penentuan responden menggunakan metode bola salju dengan total 53 orang yang terdiri dari petani, pemasok, distributor, pengecer dan konsumen bunga potong. Hasil penelitian menunjukkan bahwa keempat jenis bunga potong yang mendominasi pasar bunga potong di Denpasar adalah mawar, krisan, merak dan malam yang gurih. Ada empat distributor besar yang mendistribusikan bunga potong ke 76 pengecer di Kota Denpasar. Bunga potong dari daerah di Jawa Barat dan Jawa Timur dikirim setiap hari. Ketika pembayaran dapat dilakukan secara tunai yang dibayarkan langsung di tempat, dengan kredit atau dengan transfer menggunakan mobile banking. Kinerja rantai pasokan dapat dilihat dari rentang pangsa petani dari 30\% - 45\% dari harga pengecer. Bagian yang memiliki pangsa petani terendah adalah bunga malam (30\%) diikuti oleh bunga mawar (35\%) kemudian bunga pikok $(36 \%)$ dan tertinggi adalah krisan (45\%). Harga saham di tingkat pemasok berkisar antara 40\% - 65\% dari harga eceran dan di tingkat distributor berkisar antara 50\% - 80\% dari harga eceran. Rasio pendapatan dan biaya didominasi oleh pengecer dengan kisaran antara 4,71 - 10,76. Setiap anggota agen pemasaran melakukan fungsi pemasaran yang berbeda tergantung pada kebutuhan termasuk: transportasi produk, penyortiran dan penilaian, pengemasan, pengemasan, pengangkutan dan distribusi. Dengan ini biaya yang dikeluarkan berdampak pada harga yang diterima konsumen akhir. Rasio konsentrasi (CR 4) di tingkat ritel adalah 42,17 atau termasuk dalam struktur pasar oligopoli yang lemah.
\end{abstract}

Kata kunci: Bunga potong, kinerja rantai pasokan 


\section{PENDAHULUAN}

Bali selain sebagai salah satu destinasi wisata utama di Indonesia juga sebagai tempat diselenggarakannya perhelatan besar baik nasional maupun internasional hampir setiap tahunnya. Dengan kegiatan-kegiatan tersebut sudah tentu membutuhan bunga potong dan rangkaiannya sebagai sarana dekorasi dan keperluan lainnya. Hal ini memberikan peluang yang besar bagi petani di Bali untuk bisnis pengembangan usaha tanaman hias khususnya bunga potong.

Sesuai data dari Direktorat Jenderal Hortikultura Kementerian Pertanian Tahun 2014 bahwa pada tahun 2012 - 2013 terjadi peningkatan kebutuhan untuk komoditas bunga dan daun potong sebesar $10,88 \%$, florikultur pot, pohon dan lanskap meningkat $5,24 \%$ dan bunga tabur meningkat $32,35 \%$. Bahkan sektor industri makanan dan kosmetik memanfaatkan bunga untuk berbagai keperluan industri makanan, minuman, obat-obatan maupun kosmetika atau minyak wangi (Dirjen Hortikultura, 2014).

Berdasarkan data awal yang didapat, diketahui bahwa tahun 2019 terdapat 76 unit toko bunga potong yang ada di Kota Denpasar. Keberadaan toko bunga potong cenderung meningkat dari tahun ke tahun. toko bunga potong ini hadir memberikan layanan dengan beragam jenis rangkaian dan menjadi indikasi bahwa permintaan berbagai jenis bunga potong dan rangkaiannya meningkat. Secara umum kebutuhan bunga potong jenis mawar, krisan, pikok, sedap malam dan jenis bunga lainnya belum dapat sediakan oleh petani di Bali secara kontinyu. Peluang ini dimanfaatkan oleh para petani bunga potong di luar Bali sebagai penyedia agar tidak terjadi stagnasi atau kekosongan bahan baku. Hal terlihat arus bunga potong yang datang dari luar Bali setiap harinya membanjiri toko bunga yang ada di Denpasar.

Disamping itu data BPS Provinsi Bali Tahun 2016 mencatat bahwa ada 281 hotel berbintang di Bali dan $90 \%$ berada Kota Denpasar dan Kabupaten Badung. Dengan jumlah hotel yang cukup banyak membuka peluang yang besar untuk bisnis bunga potong dan rangkaiannya sebagai bagian dari dekorasi eksterior dan interiornya.

Sementara itu Bali diketahui hanya ada beberapa jenis bunga potong yang dapat tumbuh dan diproduksi dengan baik sesuai agroklimat namun produksinya sangat fluktuatif. Kabupaten yang memproduksi bunga potong sesuai laporan BPS dalam kurun waktu tahun 2012 -2016 dan angka sementara 2017 terkonsentrasi berada di Kabupaten Buleleng, Tabanan, Gianyar, Karangasem, Badung dan Denpasar. Sebagai sentra produksi tanaman hias yang ada di Kabupaten Buleleng, jenis tanaman hias yang diusahakan antara lain krisan, anggrek;
Kabupaten Tabanan adalah anggrek, heliconia, anthurium, krisan, mawar, bunga matahari, dan sedap malam. Kabupaten Gianyar budidaya tanaman anggrek, heliconia, anthurium, Kabupaten Badung mengusahakan anggrek, anthurium, gerbera, heliconia, krisan, mawar dan sedap malam; Kabupaten Karangasem budidaya anggrek, Kota Denpasar budidaya anggrek, heliconia.

Rantai pasok merupakan suatu proses terintegrasi sejak dari penyediaan bahan baku sampai diubah menjadi produk jadi dan di distribusikan ke pelanggan atau konsumen. Heizer, et al (2005) menyatakan bahwa manajemen rantai pasok adalah pengintegrasian aktivitas pengadaan bahan dan pelayanan, pengubahan menjadi barang setengah jadi dan produk akhir serta pengiriman ke pelanggan. Menurut Simchi-Levi, et al (2008), SCM adalah suatu pendekatan dalam mengintegrasikan berbagai organisasi yang menyelenggarakan pengadaan atau penyaluran barang yaitu supplier, manufacturer, warehouse dan stores sehingga barang-barang tersebut dapat diproduksi dan di distribusikan dalam jumlah yang tepat, lokasi yang tepat, waktu yang tepat dan biaya yang seminimal mungkin. Menurut Pujawan (2005), manajemen rantai pasokan adalah metode, alat, atau pendekatan integratif untuk mengelola aliran produk, informasi, dan uang secara terintegrasi yang melibatkan pihak-pihak mulai dari hulu ke hilir yang terdiri dari supplier, pabrik, jaringan distribusi maupun jasa-jasa logistik.

Bunga potong merupakan produk pertanian yang mudah rusak atau layu sehingga dalam mempertahankan kesegaran produk, mulai bunga potong dipanen, dikemas, dikirim bahkan sampai hasil rangkaian diterima oleh pelanggan atau konsumen harus dalam keadaan segar. Kesemuanya itu merupakan suatu rangkaian kegiatan rantai pasok yang melibatkan berbagai unsur di dalamnya. Hal tersebut yang menjadi dasar penelitian mengenai kinerja rantai pasok bunga potong di Kota Denpasar penting untuk diteliti. Bertujuan untuk menganalisis fungsi dan kelembagaan rantai, untuk menganalisis kinerja dan menganalisis posisi industri pemasaran bunga potong di Kota Denpasar.

\section{METODE PENELITIAN}

Penelitian berlokasi di Kota Denpasar, Bali. Pemilihan lokasi dilakukan secara purposive dengan mempertimbangkan : a) bahwa kebutuhan bunga potong di Kota Denpasar cenderung meningkat yang ditandai dengan bertambahnya toko bunga potong. Pada Tahun 1975 hadirnya satu toko bunga yang berdiri di Kota Denpasar. Lambat laun toko bunga berkembang dengan rata-rata pertumbuhan 1-4 unit/tahun dan pada tahun 2019 telah mencapai 76 unit, belum termasuk usaha bunga potong rumahan yang berbasis on line, $b$ ) belum pernah dilakukan penelitian mengenai kinerja rantai pasok bunga potong di Kota Denpasar. 
Ragam Populasi dalam penelitian ini terdiri dari petani produsen, supplier, distributor, pedagang pengecer dan konsumen, yang berdomisili di Kota Denpasar, Kab. Malang, Kab. Pasuruan Kec. Rembang dan Pancasari, Bali. Untuk mendapatkan responden, teknik penarikan sampelnya menggunakan metode nonprobabilitas dengan pengambilan sampel sebanyak 53 orang menggunakan snowball sampling (bola salju).

Analisis fungsi dan kelembagaan bunga potong dilakukan secara diskriptif kualitatif mulai dari tahap pemanenan bunga potong di tingkat petani sampai di tingkat pengecer di Kota Denpasar. Untuk analisis kinerja rantai pasok digunakan dengan mengukur tingkat efisiensi rantai pasokan.

Pengukurannya memperhitungkan biaya-biaya yang dikeluarkan untuk kepentingan pemasaran produk dan persentase keuntungan dari masing-masing anggota rantai pasok. Efisiensi rantai pasok digambarkan dengan menghitung persentase keuntungan setiap anggota rantai pasok. Untuk konsentrasi pasar diukur dengan Rasio Konsentrasi (CR).

\section{HASIL DAN PEMBAHASAN}

Hasil tabulasi data diketahui bahwa secara umum bunga potong yang mendominasi bursa bunga potong di Kota Denpasar ada empat jenis antara lain jenis mawar, krisan, pikok dan sedap malam. Dengan ditunjang oleh sarana transportasi darat dan udara yang lancar, ketersediaan bunga potong tidak mengalami kesulitan atau stok bunga potong yang di Kota Denpasar tidak pernah mengalami kekosongan karena selalu ada pengiriman dari daerah sentra bunga potong seperti yang dapat dilihat pada Tabel 1.

Tabel 1. Rerata Pengiriman Bunga Potong Per Bulan ke Bali Tahun 2019

\begin{tabular}{cccccc}
\hline & & \multicolumn{4}{c}{ Jenis Bunga } \\
\cline { 3 - 6 } No & $\begin{array}{c}\text { Asal } \\
\text { Bunga }\end{array}$ & $\begin{array}{c}\text { Mawar } \\
\text { (tangkai) }\end{array}$ & $\begin{array}{c}\text { Krisan } \\
\text { (tangkai) }\end{array}$ & $\begin{array}{c}\text { Pikok } \\
\text { (ikat) }\end{array}$ & $\begin{array}{c}\text { Sedap } \\
\text { malam } \\
\text { (tangkai) }\end{array}$ \\
\hline 1 & Malang & 326.977 & 1.527 .750 & 4.950 & \\
& & & & 930.000 \\
2 & $\begin{array}{c}\text { Rembang } \\
\text { Pasuruan }\end{array}$ & & & & \\
\hline
\end{tabular}

\begin{tabular}{lllll} 
Jumlah & 326.977 & 1.527 .750 & 4.950 & 930.000 \\
\hline
\end{tabular}

Sementara untuk mengetahui rata-rata permintaan bunga potong yang dominan di Kota Denpasar dapat dilihat pada Tabel 2.

Tabel 2. Rerata Permintaan Bunga Potong Per Bulan

\begin{tabular}{clc}
\hline No & Jenis Bunga & $\begin{array}{c}\text { Jumlah Permintaan } \\
\text { Per bulan (Tangkai) }\end{array}$ \\
\hline 1 & Mawar & 179.714 \\
2 & Sedap Malam & 122.840 \\
3 & Krisan & 62.740 \\
4 & Pikok (ikat) & 47.040 \\
\hline
\end{tabular}

Fungsi pemasaran bunga potong meliputi proses pembelian, penjualan, pemanenan, pengangkutan, sortasi dan grading, pengikatan bunga, pengemasan dan pengepakan, pengiriman dan distribusi. Petani melakukan fungsi pemasaran pada proses pemanenan, pengumpulan hasil panen dan penjualan. Suplier melakukan fungsi pemasaran meliputi, pembelian bunga potong dari petani, pengangkutan dari kebun, sortasi dan grading, pengemasan, penjualan dan pengiriman kepada distributor dan pengecer. supplier, biasanya melakukan penyimpanan yang bersifat sementara sebelum di distribusikan.

Distributor melakukan fungsi pemasaran meliputi pembelian produk bunga potong, sortasi, pengemasan dan penjualan dan pendistribusian kepada pengecer. Para pengecer melakukan fungsi pemasaran meliputi pembelian bunga potong dari distributor dan supplier, melakukan sortasi dan grading untuk dapat menjual produk sesuai mutu dan memisahkan bunga potong yang masih segar dan dan mulai nampak rusak.

Deklator dalam melakukan fungsi yaitu pemesanan dan pembelian produk, grading sesuai kualitas yang diperoleh. Dengan demikian masing-masing anggota rantai pasok melakukan proses pada setiap fungsi pemasaran tidak selalu sama. Fungsi dan peranan pemasaran adalah mengusahakan agar pembeli bunga potong memperoleh barang yang diinginkan pada tempat, waktu, bentuk dan harga yang tepat. Fungsi meningkatkan kegunaan tempat, kegunaan waktu dan kegunaan bentuk. Fungsi pertukaran (pembelian dan penjualan), fungsi penyediaan/fisik (pengangkutan dan penyimpanan) dan fungsi penunjang (penanggungan resiko, standardisasi \& grading, pembiayaan \& informasi pasar) merupakan bagian yang tidak terpisahkan dalam suatu lembaga pemasaran.

Menurut Susrusa (2018), pasar dalam bentuknya yang paling awal, pemasaran didefinisikan dengan sederhana berdasar pada produk, yaitu sebagai suatu proses yang berkenaan dengan pertukaran antara satu produk dengan produk lainnya. Pada pertukaran produk yang dijual tersebut, penjual menerima produk lain dari pembeli demikian pula sebaliknya. Menurut Indrajit (2002), pemain utama dalam rantai pasok di antaranya suppliers, manufacture, distributor, retail outlets, dan customers Secara umum rantai pasok pemasaran bunga potong dapat dilihat pada Gambar 1.

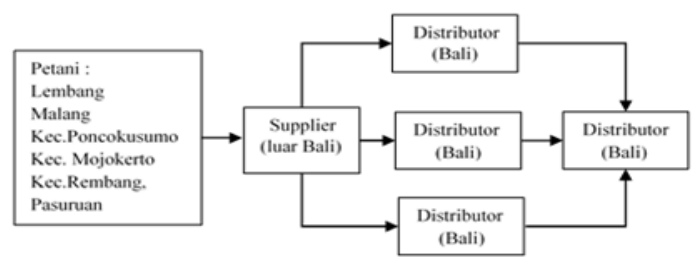

Gambar 1. Rantai Pasok Pemasaran Bunga Potong 
Tabel 3 tentang kinerja rantai pasok bunga potong yang terlihat pada farmer's share yang berkisar terendah sebesar $30 \%$ pada bunga sedap malam, disusul bunga mawar sebesar 35\%, kemudian bunga pikok sebesar $36 \%$ dan tertinggi sebesar $45 \%$ pada bunga krisan dari harga pengecer.

Tabel 3. Farmer's Share Harga Empat Jenis Bunga Potong

\begin{tabular}{lccc}
\hline & $\begin{array}{c}\text { Pendapatan } \\
(\mathrm{P})\end{array}$ & $\begin{array}{c}\text { Biaya } \\
(\mathrm{B})\end{array}$ & \multirow{2}{*}{$\mathrm{P} / \mathrm{B}$} \\
\cline { 2 - 3 } & \multicolumn{2}{c}{$(\mathrm{Rp} / 10$ Tangkai $)$} & \\
\hline Supplier & 2.475 & 525 & 4,71 \\
Distributor & 4.240 & 760 & 5,58 \\
Pengecer & 4.245 & 755 & 5,62 \\
\hline
\end{tabular}

Sementara share harga pada tingkat supplier yang terendah sebesar $40 \%$ pada bunga sedap malam, disusul kemudian bunga pikok sebesar $48 \%$, bunga mawar sebesar $50 \%$ dan tertinggi sebesar $65 \%$ adalah bunga krisan dari harga pengecer. Share harga pada tingkat supplier dapat dilihat pada Tabel 4.

Tabel 2. Share Harga di Tingkat Supplier pada Empat Jenis Bunga Potong

\begin{tabular}{ccccc}
\hline \multirow{2}{*}{ No } & \multirow{2}{*}{ Jenis Bunga } & \multicolumn{2}{c}{ Harga (Rp) } & \multirow{2}{*}{ Share (\%) } \\
\cline { 3 - 4 } & Petani & Pengecer & \\
\hline 1 & Mawar (btg) & 1.000 & 2.000 & 50 \\
2 & Krisan (btg) & 1.000 & 2.000 & 65 \\
3 & Pikok (ikat) & 12.000 & 25.000 & 48 \\
4 & Sedap malam (btg) & 800 & 2.000 & 40 \\
\hline
\end{tabular}

Pada Tabel 5 untuk melihat share harga di tingkat distributor yang terendah sebesar 50\% pada bunga sedap malam, untuk bunga mawar dan krisan memperoleh share harga yang sama sebesar $75 \%$ dan tertinggi sebesar $80 \%$ yakni bunga pikok. Hasil perbandingan rasio keuntungan dan biaya pemasaran tertinggi didominasi oleh pengecer karena faktor beban biaya dan resiko kerusakan terbesar di level pengecer.

Tabel 5. Share Harga di Tingkat Supplier

\begin{tabular}{llccc}
\hline \multirow{2}{*}{ No } & \multirow{2}{*}{ Jenis Bunga } & \multicolumn{2}{c}{ Harga (Rp) } & \multirow{2}{*}{ Share (\%) } \\
\cline { 3 - 4 } & & Petani & Pengecer & \\
\hline 1 & Mawar (btg) & 1.500 & 2.000 & 75 \\
2 & Krisan (btg) & 1.500 & 2.000 & 75 \\
3 & Pikok (ikat) & 20.000 & 25.000 & 80 \\
4 & Sedap malam (btg) & 1.000 & 2.000 & 50 \\
\hline
\end{tabular}

Melihat rasio keuntungan dan biaya pemasaran bunga mawar pada Tabel 6 bahwa keuntungan yang diraih oleh pengecer adalah sebesar Rp 4.245,00/10 tangkai dengan biaya yang dikeluarkan untuk melakukan fungsi-fungsi pemasaran adalah sebesar Rp 755,00/10 tangkai bunga mawar. Dengan demikian pengecer memperoleh rasio $\mathrm{K} / \mathrm{B}$ sebesar Rp 5,62 yang dapat diartikan bahwa jika ada pengeluaran biaya pemasaran sebesar Rp 1,00 maka memperoleh keuntungan sebesar Rp 5,62.

Tabel 6. Rasio Pendapatan dan Biaya Pemasaran Bunga Potong Jenis Mawar

\begin{tabular}{llcc}
\hline & $\begin{array}{c}\text { Pendapatan } \\
(\mathrm{P})\end{array}$ & $\begin{array}{c}\text { Biaya } \\
(\mathrm{B})\end{array}$ & \multirow{2}{*}{$\mathrm{P} / \mathrm{B}$} \\
\cline { 2 - 3 } & \multicolumn{2}{c}{$(\mathrm{Rp} /$ 10 Tangkai) } & \\
\hline Supplier & 2.475 & 525 & 4,71 \\
Distributor & 4.240 & 760 & 5,58 \\
Pengecer & 4.245 & 755 & 5,62 \\
\hline
\end{tabular}

Hasil penelitian yang dilakukan oleh Puspasari, et al. (2017) tentang analisis efisiensi pemasaran bunga mawar potong (Studi Kasus di Desa Gunungsari, Kecamatan Bumiaji, Kota Batu), ada kenaikan harga di tingkat petani dari Rp 6.000,00/10 tangkai, pada tahun 2019 menjadi Rp 7.000,00,/10 tangkai atau ada kenaikan harga $16,5 \%$. Hal ini wajar karena adanya penyesuaian/perubahan harga sarana produksi (input). Sementara Mubarok, et al. (2018) dalam penelitian tentang penghambatan respons etilen pada mawar potong melalui modifikasi larutan perendam, 1-MCP, dan Sitokinin, menjelaskan bahwa bunga mawar potong mempunyai tingkat kesegaran bunga yang singkat hanya berkisar antara 4-5 hari setelah panen. Namun menurut Ridhawardani, et al. (2017) meneliti tentang analisis efisiensi pemasaran bunga mawar potong di Desa Kertawangi, Kecamatan Cisarua, Kabupaten Bandung Barat, menyatakan bahwa harga bunga potong jenis mawar ditingkat petani sebesar Rp 1.250,00/tangkai dan di tingkat pengecer sebesar Rp 7.000,00/tangkai. Petani yang memiliki luas lahan di bawah satu hektar dan modal yang terbatas tidak pernah menjual langsung ke pedagang besar karena tidak adanya koneksi antara petani dengan pedagang besar. Penyebab margin harga yang tinggi disebabkan produk yang dihasilkan melalui perantara-perantara seperti pedagang pengumpul, bandar/tengkulak, pedagang besar dan pedagang pengecer yang biaya pemasarannya dikeluarkan oleh setiap lembaga pemasaran cukup tinggi.

Untuk melihat aliran uang dan selisih yang diterima dari masing-masing pihak yang terlibat dalam aliran rantai pasok bunga potong seperti pada Tabel 7 . 
Tabel 3. Analisa Rantai Nilai Bunga Mawar Per 10 batang

\begin{tabular}{lrrrrr}
\hline $\begin{array}{l}\text { Komponen harga } \\
\quad \text { biaya }\end{array}$ & Petani & Supplier & Distributor & Pengecer & Konsumen \\
\hline Harga jual & 7.000 & 10.000 & 15.000 & 20.000 & \\
Harga beli & & 7.000 & 10.000 & 15.000 & 20.000 \\
Biaya-biaya: & 525 & 760 & 755 & \\
- Sortasi dan & & & & & \\
grading & 60 & 60 & 100 & \\
- Pengemasan & & 200 & 150 & 255 & \\
- resiko & 125 & 400 & 400 & \\
- bongkar muat & & 40 & 80 & - & - \\
- transportasi & & 100 & 70 & 4.245 & \\
- margin & & 2.475 & 4,240 & 4.000 & 20.000 \\
Jumlah pendapatan & 7.000 & 10.000 & 15.000 & 4.245 & \\
Keuntungan & & 2.475 & 4.240 & & \\
Pendapatan/Biaya & & & & 5.62 \\
(P/B) & & 4.71 & 5.58 & & \\
\hline
\end{tabular}

Hasil analisa rantai nilai bunga potong jenis mawar per 10 batang dapat dijelaskan bahwa harga jual di tingkat petani sebesar Rp7.000,00. Harga bunga di tingkat dengan supplier sebesar Rp 10.000,00. Terdapat selisih harga di tingkat petani sebesar Rp 3.000,00. Selisih tersebut diperuntukan komponen biaya lain-lain sebesar $\mathrm{Rp} 525,00$ dan margin keuntungan yang diperoleh sebesar $\mathrm{Rp} 2.475,00$. Harga bunga potong di tingkat distributor sebesar Rp 15.000,00, terdapat selisih harga dengan supplier sebesar Rp 5.000,00 yang diperuntukkan komponen biaya sebesar $\mathrm{Rp} 760,00$ dan margin keuntungan sebesar $\mathrm{Rp}$ 4.240,00. Harga bunga ditingkat pengecer sebesar Rp 20.000,00. Selisih harga dengan distributor sebesar Rp 5.000,00 yang diperuntukkan komponen biaya sebesar $\mathrm{Rp} 755,00$ dan margin keuntungan yang diperoleh sebesar Rp 4.245,00. Perolehan margin distributor dan pengecer lebih besar cukup beralasan karena adanya faktor resiko dan biaya yang harus ditanggung lebih besar.

Selisih harga dari masing-masing anggota rantai pasok bunga mawar dapat disimpulkan bahwa pada setiap aktivitas kegiatan fungsi pemasaran ada konsekwensi dari aktivitas tersebut yang dapat memberikan pertambahan nilai (biaya dan keuntungan). Secara umum bunga mawar setelah panen dapat bertahan paling lama tujuh hari dengan suhu yang rendah. Sementara di Kota Denpasar dengan suhu udara yang cukup terik di siang hari membuat distributor dan pengecer melakukan penanganan ekstra untuk mempertahankan kesegaran bunga. Berkaitan dengan tingkat kesegaran bunga potong jenis mawar, menurut Mubarok, et al. (2018) dalam penelitian tentang penghambatan respons etilen pada mawar potong melalui modifikasi larutan erendam, 1-MCP, dan Sitokinin, menjelaskan bahwa bunga mawar potong mempunyai tingkat kesegaran bunga yang singkat hanya berkisar antara 4-5 hari setelah panen. Penurunan kualitas bunga umumnya terjadi pada saat penyimpanan yang disebabkan oleh suhu tinggi dan infeksi mikroorganisme (Amiarsi et al, 2003).

Hasil penelitian yang dilakukan oleh Puspasari, et al. (2017) tentang analisis efisiensi pemasaran bunga mawar potong (Studi Kasus di Desa Gunungsari, Kecamatan Bumiaji, Kota Batu), Untuk mengetahui efisiensi pemasaran digunakan dua alat pengukuran yaitu Untuk mengetahui efisiensi pemasaran digunakan dua alat pengukuran yaitu, efisiensi harga (pricing efficiency) dan efisiensi operasional (operational efficiency) Hasil penelitian tersebut menunjukkan bahwa banyaknya lembaga pemasaran yang terlibat akan menentukan perbedaan harga ditingkat konsumen. Semakin banyaknya lembaga pemasaran yang ikut terlibat dalam proses penyampaian komoditas bunga mawar pototng ini, maka akan semakin tinggi perbadaan harga ditingkat konsumen yang menyebabkan share yang diterima oleh petani menjadi semakin kecil. Share harga bagi petani ini belum mencerminkan suatu keadilan, dikarenakan resiko yang ditanggung oleh petani cukup besar namun hasil yang didapatkan dalam berusaha tani ini tidak sebanding dengan resikonya. Share yang didapat oleh petani dan lembaga pemasaran bunga mawar potong ini berbeda-beda tergantung pada biaya-biaya yang dikeluarkan untuk melakukan fungsi-fungsi pemasaran serta keuntungan yang didapat oleh petani dan lembaga pemasaran.

Penelitian yang dilakukan oleh Ridhawardani, et al. (2017) tentang analisis efisiensi pemasaran bunga mawar potong di Desa Kertawangi, Kecamatan Cisarua, Kabupaten Bandung Barat, menyatakan bahwa harga bunga potong jenis mawar ditingkat petani sebesar Rp 1.250,00/batang dan di tingkat pengecer sebesar Rp 7.000,00/batang. Petani yang memiliki luas lahan di bawah satu hektar dan modal yang terbatas tidak pernah menjual langsung ke pedagang besar karena tidak adanya koneksi antara petani dengan pedagang besar. Penyebab margin harga yang tinggi disebabkan banyak melalui rantai yang panjang sehingga biaya pemasarannya dikeluarkan oleh setiap lembaga pemasaran cukup tinggi.

Tabel 8 tentang rasio keuntungan dan biaya pemasaran bunga potong jenis krisan menjelaskan bahwa perolehan keuntungan pada pemasaran jenis bunga potong krisan paling besar diperoleh pengecer dengan nilai $\mathrm{Rp} 4.350,00 / 10$ tangkai dengan rasio $\mathrm{K} / \mathrm{B}$ sebesar Rp 6,69 yang berarti dengan pengeluaran biaya pemasaran sebesar Rp 1,00 maka keuntungan yang diperoleh sebesar Rp 6,69. Hal ini cukup beralasan proses sortasi, pengemasan dan resiko yang ditanggung lebih besar dari supplier dan distributor. Penggunaan ruang pendingin atau alat pendingin untuk membantu kesegaran bunga potong sampai bunga potong terjual. Hasil penelitian yang dilakukan oleh Andri, et al. (2013) menunjukkan bahwa harga bunga krisan di tingkat petani sebesar Rp 900,00/tangkai dan harga bunga krisan pada tahun 2019 juga masih sebesar Rp 900,00/tangkai. Hal ini dikarenakan penerapan strategi low cost, 
keunikan produk dan penerapan inovasi teknologi sesuai yang diinginkan.

Tabel 8. Rasio Pendapatan dan Biaya Pemasaran Bunga Potong Jenis Krisan

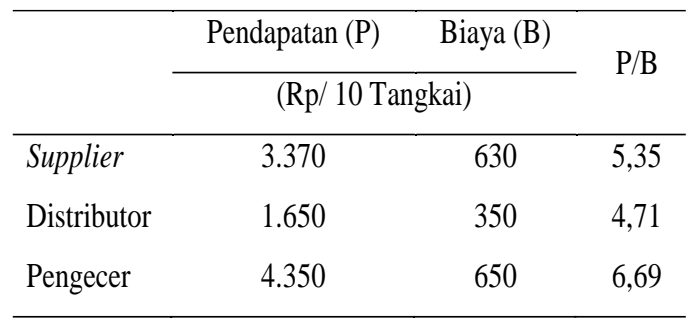

Hasil analisa rantai nilai bunga potong jenis krisan per 10 batang dapat dijelaskan bahwa harga jual di tingkat petani sebesar Rp 9.000,00. Harga bunga di tingkat dengan supplier sebesar Rp 13.000,00. Terdapat selisih harga di tingkat petani sebesar Rp 4.000,00. Selisih tersebut diperuntukan komponen biaya lain-lain sebesar $\mathrm{Rp} 630,00$ dan margin keuntungan yang diperoleh sebesar Rp. 3.370,00. Harga bunga potong di tingkat distributor sebesar Rp $15.000,00$, terdapat selisih harga dengan supplier sebesar Rp 2.000,00 yang diperuntukkan komponen biaya sebesar $\mathrm{Rp} 350,00$ dan margin keuntungan sebesar Rp 1.650,00. Harga bunga ditingkat pengecer sebesar Rp 20.000,00. Selisih harga dengan distributor sebesar Rp 5.000,00 yang diperuntukkan komponen biaya sebesar Rp 650,00 dan margin keuntungan yang diperoleh sebesar $\mathrm{Rp} 4.350,00$. Perolehan margin pengecer lebih besar cukup beralasan karena adanya faktor resiko dan biaya yang harus ditanggung lebih besar. Sedangkan margin di tingkat supplier kecil karena komponen biaya tetap sehingga margin keuntungan hanya diperoleh sedikit. Faktor pembentuk harga bunga krisan yang tinggi pada tingkat petani dikarenakan biaya yang dikeluarkan dalam proses pembungaan krisan lebih sulit perlu tingkat pencahayaan yang tinggi dengan frekwensi penyinaran yang panjang membuat harga ditingkat petani berbeda dengan bunga mawar.

Tabel 4. Analisa Rantai Nilai Bunga Krisan Per 10 batang

\begin{tabular}{|c|c|c|c|c|c|}
\hline $\begin{array}{c}\text { Komponen harga } \\
\text { /biaya }\end{array}$ & Petani & Supplier & Distributor & Pengecer & Konsumen \\
\hline \multicolumn{6}{|l|}{ Harga jual } \\
\hline & 9.000 & 13.000 & 15.000 & 20.000 & \\
\hline Harga beli & & 9.000 & 13.000 & 15.000 & 20.000 \\
\hline Biaya-biaya: & & 630 & 350 & 650 & \\
\hline \multicolumn{6}{|l|}{-Sortasi dan } \\
\hline grading & & 80 & 50 & 125 & \\
\hline - Pengemasan & & 100 & 50 & 175 & \\
\hline - resiko & & 250 & 150 & 350 & \\
\hline - bongkar muat & & 100 & 50 & & \\
\hline - transportasi & & 100 & 50 & & \\
\hline - margin & & 3.370 & 1.650 & 4.350 & \\
\hline Jumlah pendapatan & 9.000 & 13.000 & 15.000 & 20.000 & \\
\hline Keuntungan & & 3.370 & 1.650 & 4.350 & \\
\hline \multicolumn{6}{|l|}{ Pendapatan/Biaya } \\
\hline$(\mathrm{P} / \mathrm{B})^{2}$ & & 5.35 & 4.71 & 6.69 & \\
\hline
\end{tabular}

Dari hasil perolehan rasio $\mathrm{k} / \mathrm{b}$ tertinggi diperoleh pengecer dengan rasio keuntungan bunga potong jenis pikok sebesar Rp7.320/ikat bunga pikok dengan biaya yang dikeluarkan sebesar Rp 680,00/10 tangkai sehingga pengecer memperoleh keuntungan sebesar Rp 10,76 yang dapat diartikan bahwa jika ada peningkatan biaya pemasaran bunga pikok sebesar $\mathrm{Rp} 1,00$ maka nilai rasio K/B meningkat sebesar Rp 10,76.

Tabel 5. Rasio Pendapatan dan Biaya Pemasaran Bunga Pikok

\begin{tabular}{|c|c|c|c|}
\hline & Pendapatan $(\mathrm{P})$ & Biaya (B) & \multirow{2}{*}{$\mathrm{P} / \mathrm{B}$} \\
\hline & \multicolumn{2}{|c|}{ (Rp/ 10 Tangkai) } & \\
\hline Supplier & 2.550 & 450 & 5,67 \\
\hline Distributor & 7.320 & 680 & 10,76 \\
\hline Pengecer & 4.400 & 600 & 7,33 \\
\hline
\end{tabular}

Pada hasil perhitungan untuk jenis bunga Pikok diketahui harga ditingkat petani sebesar Rp 9.000,00/ ikat dijelaskan bahwa faktor pembentuk harga yang tinggi dikarenakan ditanam selama empat bulan hanya dapat dipanen sekali saja dalam satu siklus. Terlihat bahwa pada bagian distributor memperoleh selisih yang lebih besar dari supplier, pengecer bahkan petani. Hal ini disebabkan karena keperluan bunga pikok hanya sedikit dan tidak mendominasi suatu rangkaian bunga. Untuk itu persediaan bunga pikok lebih banyak di tingkat distributor yang berdampak pada biaya perawatan dan resiko yang ditanggung lebih besar.

Kebanyakan bunga pikok disediakan oleh dalam jumlah banyak dan pengecer membeli dalam jumlah terbatas. Hal ini membuat margin keuntungan yang di peroleh lebih besar untuk dapat menekan komponen biaya yang mungkin akan meningkat. Faktor resiko kerusakan yang harus ditanggung, beban biaya perawatan baik ruang pendingan atau penggunaan alat pendingin, tenaga kerja, biaya sewa tempat menjadi pertimbangan tambahan.

Pada hasil perhitungan untuk jenis bunga Pikok diketahui harga ditingkat petani sebesar Rp 9.000,00/ikat dijelaskan bahwa faktor pembentuk harga yang tinggi dikarenakan ditanam selama empat bulan hanya dapat dipanen sekali saja dalam satu siklus. Terlihat bahwa pada bagian distributor memperoleh selisih yang lebih besar dari supplier, pengecer bahkan petani. Hal ini disebabkan karena keperluan bunga pikok hanya sedikit dan tidak mendominasi suatu rangkaian bunga. 
Tabel 11. Analisa Rantai Nilai Bunga Pikok Per ikat

\begin{tabular}{lrrrrr}
\hline \begin{tabular}{l} 
Komponen harga \\
\multicolumn{1}{c}{ biaya }
\end{tabular} & Petani & Supplier & Distributor & Pengecer & Konsumen \\
\hline Harga jual & 9.000 & 12.000 & 20.000 & 25.000 & \\
Harga beli & & 9.000 & 12.000 & 20.000 & 25.000 \\
Biaya-biaya: & & 450 & 680 & 600 & \\
-Sortasi dan & & & & & \\
grading & & 100 & 110 & 100 & \\
- Pengemasan & & 100 & 150 & 100 & \\
- resiko & & 100 & 150 & 400 & \\
- bongkar muat & & 50 & 100 & - & \\
- transportasi & & 100 & 170 & - & - \\
- margin & & 2.550 & 7.320 & 4.400 & \\
Jumlah pendapatan & 9.000 & 12.000 & 20.000 & 25.000 & \\
Keuntungan & & 2.550 & 7.320 & 4.400 & \\
Pendapatan/Biaya & & & & & \\
(P/B) & 5.67 & 10.76 & 7.33 & \\
\hline
\end{tabular}

Tabel 12 tentang hasil perhitungan bunga sedap malam, keuntungan tertinggi yang diperoleh adalah pengecer dengan nilai keuntungan sebesar $\mathrm{Rp}$ $8.800,00 / 10$ tangkai bunga potong dan biaya yang dikeluarkan sebesar Rp 1.200,00 sehingga rasio K/B yang diperoleh pengecer sebesar $\mathrm{Rp}$ 7,33 yang berarti setiap pengeluaran biaya $\mathrm{Rp}$ 1,00 maka diperoleh keuntungan sebesar Rp 7,33.

Tabel 12. Rasio Pendapatan dan Biaya Pemasaran Bunga Potong Jenis Sedap Malam

\begin{tabular}{|c|c|c|c|}
\hline & Pendapatan $(\mathrm{P})$ & Biaya (B) & \multirow{2}{*}{$\mathrm{P} / \mathrm{B}$} \\
\hline & \multicolumn{2}{|c|}{ (Rp/ 10 Tangkai) } & \\
\hline Supplier & 1.700 & 300 & 5,67 \\
\hline Distributor & 1.650 & 350 & 4,71 \\
\hline Pengecer & 8.800 & 1.200 & 7,33 \\
\hline
\end{tabular}

Sesuai hasil penelitian yang dilakukan oleh Adawiyah (2017) tentang strategi bunga sedap malam (Polianthes Tuberosa) dalam menghadapi pasar di Desa Pekoren, Kecamatan Rembang, Kabupaten Pasuruan, menjelaskan bahwa terdapat fluktuasi harga bunga sedap malam yang cukup tinggi. Harga yang ditawarkan dalam beberapa tipe. Untuk tipe A (kuntum besar) harga jualnya yaitu antara Rp 500,00 - Rp 2.500,00; tipe B mempunyai kuntum sedang dengan harga jual antara Rp 300,00 $\mathrm{Rp} 1.000,00$ dan tipe $\mathrm{C}$ mempunyai kuntum kecil dengan harga jual Rp 200,00 - Rp 800,00. Hal ini cukup beralasan karena pembeli pada umumnya tertarik pada bunga sedap malam yang berkualitas baik meskipun dengan harga yang cukup tinggi. Harga bunga sedap malam di sentra produksi sangat bervariasi karena dipengaruhi oleh beberapa sebab antara lain keadaan iklim yang sulit diprediksi sehingga pertumbuhan bunga sedap malam mengalami hambatan, adanya perayaan hari besar/upacara keagamaan atau perayaan lainnya menurut kalender Jawa dan permintaan tertentu dari luar daerah produksi. Hal ini menurut Sinaga, et al. (2015) dalam penelitian tentang analisis strategi pemasaran bunga potong (Studi Kasus : Desa Raya Kecamatan Berastagi Kabupaten Karo Provinsi Sumatera Utara) menjelaskan bahwa perlu mengetahui faktor internal dan eksternal yang dapat mempengaruhi strategi pemasaran bunga potong secara umum. Sedangkan faktor eksternal adalah lokasi pasar, harga, jumlah permintaan, permodalan, promosi dan dukungan pemerintah daerah.

Tabel 13. Analisa Rantai Nilai Bunga Sedap malam per 10 batang

\begin{tabular}{lrrrrr}
\hline \begin{tabular}{l} 
Komponen harga \\
\multicolumn{1}{c}{ /biaya }
\end{tabular} & Petani & Supplier & Distributor & Pengecer & Konsumen \\
\hline Harga jual & 6.000 & 8.000 & 10.000 & 20.000 & \\
Harga beli & & 6.000 & 8.000 & 10.000 & 20.000 \\
Biava-biaya: & & 300 & 350 & 1.200 & \\
-Sortasi dan & & & & & \\
grading & & 50 & 50 & 200 & \\
- Pengemasan & & 50 & 50 & 500 \\
- resiko & & 50 & 75 & 500 & \\
- bongkar muat & & 50 & 75 & & \\
- transportasi & & 100 & 100 & \\
- margin & & 1.700 & 1.650 & 8.800 \\
Jumlah pendapatan & 6.000 & 8.000 & 10.000 & 20.000 & \\
Keuntungan & & 1.700 & 1.650 & 8.800 & \\
Pendapatan/Biaya & & & & \\
(P/B) & & 5.67 & 4.71 & 7.33 \\
\hline
\end{tabular}

Hasil analisa rantai nilai bunga potong jenis sedap malam per 10 batang dapat dijelaskan bahwa harga jual di tingkat petani sebesar Rp 6.000,00. Harga bunga di tingkat dengan supplier sebesar Rp $8.000,00$. Terdapat selisih harga di tingkat petani sebesar Rp 2.000,00. Selisih tersebut diperuntukkan komponen biaya lain-lain sebesar Rp 300,00 dan margin keuntungan yang diperoleh sebesar $\mathrm{Rp}$. 1.700,00. Harga bunga potong di tingkat distributor sebesar Rp 10.000,00, terdapat selisih harga dengan supplier sebesar Rp 2.000,00 yang diperuntukkan komponen biaya sebesar Rp 360,00 dan margin keuntungan sebesar Rp 1.650,00. Harga bunga ditingkat pengecer sebesar Rp 20.000,00. Selisih harga dengan distributor sebesar Rp 10.000,00 yang diperuntukkan komponen biaya sebesar Rp 1.200,00 dan margin keuntungan yang diperoleh sebesar $\mathrm{Rp}$ $8.800,00$. Perolehan margin pengecer lebih besar dari supplier dan distributor cukup beralasan karena adanya faktor resiko dan biaya yang harus ditanggung lebih besar serta penampilan fisik bunga (panjang atau pendeknya tangkai) yang menjadi salah satu pilihan dalam membeli bunga sedap malam. Selisih harga yang cukup mencolok serta biaya sewa tempat usaha dan upah tenaga kerja yang dapat disediakan dari pos pendapatan ini.

Harga bunga sedap malam yang cenderung stabil dapat diketahui bahwa dalam satu kali penanaman 
dapat dilakukan pemanenan selama dua tahun atau lebih, tergantung perawatan. Oleh sebab itu harga ditingkat petani tidak terlalu tinggi. Selisih harga dari masing-masing anggota rantai pasok cenderung sama kecuali pada tingkat pengecer yang dapat disimpulkan bahwa aktivitas kegiatan fungsi pemasaran sedap malam ada konsekwensi dari aktivitas yang memberikan pertambahan nilai (biaya dan keuntungan). Terlihat bahwa pada bagian pengecer memperoleh selisih yang lebih besar dari supplier, distributor bahkan petani. Hal ini disebabkan karena bunga sedap malam kerap menjadi bunga yang dominan pada beberapa jenis rangkaian tertentu sesuai permintaan konsumen. Untuk itu persediaan bunga lebih banyak di tingkat pengecer yang berdampak pada biaya perawatan dan resiko yang lebih besar ditanggung.

Tabel 14. Peringkat Volume Penjualan Bunga Potong

\begin{tabular}{ccccc}
\hline No & $\begin{array}{r}\text { No.Urut } \\
\text { Responden }\end{array}$ & $\begin{array}{r}\text { Volume } \\
\text { Penjualan }\end{array}$ & CR4 & Peringkat \\
\hline 1 & 22 & 67,975 & 17.72 & 1 \\
2 & 6 & 40,200 & 10.48 & 2 \\
3 & 17 & 28,224 & 7.36 & 3 \\
4 & 15 & 25,360 & 6.61 & 4 \\
\hline
\end{tabular}

$$
\begin{aligned}
\text { CR4 } & =\text { Pelaku } 22+\text { Pelaku } 6+\text { Pelaku } 17+\text { Pelaku } \\
& 15 \\
& =17,72+10,48+7,36+6,61 \\
& =42,17
\end{aligned}
$$

Hasil perhitungan Tabel 14 tentang konsentrasi pasar menunjukkan konsentrasi rasio berada pada CR4 = 50>CR40 (rendah) Monopolistic-Oligopoly. Hal ini sebagai indikasi bahwa sejumlah pelaku usaha pada oligopoly lemah karena rata-rata kepemilikan usaha dengan harga penjualan yang relatif sama sehingga tidak memungkinkan adanya pembentukan kartel dalam kaitannya dengan pembentukan harga. Menurut Rekarti (2016), rasio konsentrasi berkisar antara nol hingga satu dan biasanya dinyatakan dalam persentase. Nilai konsentrasi yang mendekati angka nol mengindikasikan bahwa sejumlah $n$ perusahaan memiliki pangsa pasar yang relatif kecil.

\section{SIMPULAN DAN SARAN}

\section{Simpulan}

Penelitian ini memberikan beberapa simpulan sebagai berikut: (1) Semua anggota lembaga pemasaran telah melakukan fungsi-fungsi sesuai kebutuhan. Adanya perbedaan pendapatan di masing-masing level lembaga pemasaran tergantung keuntungan dan biaya dikeluarkan untuk aktivitas yang dilakukan; (2) Rasio pendapatan dan biaya terlihat lebih besar dari Rp 1,00 yang berarti bahwa setiap biaya yang dikeluarkan memberi keuntungan lebih tinggi dari biaya besar dari Rp 1,00; (3) Pasar bunga potong bersifat oligopoli lemah karena para pelaku usaha hanya menguasai 42,17 yang dapat diartikan tidak memungkinkan adanya kartel dalam pembentukan harga.

\section{Saran}

Saran dari penelitian ini adalah: (1) Perlu dilakukan kajian tentang potensi wilayah sesuai agroklimat yang pelaksanaannya melibatkan petani di sentrasentra pengembangan bunga potong dalam rangka memenuhi konsumsi/permintaan yang terus meningkat untuk berbagai kebutuhan di Bali; (2) Perlu adanya lembaga atau instansi yang yang dapat mendokumentasikan terkait dengan permintaan dan suplay bunga potong yang masuk ke Provinsi Bali. Hal ini penting mengingat sangat minimnya data dan informasi yang berkaitan dengan bunga potong; (3) Bagi petani yang berusaha tani bunga potong di Bali maupun di luar Bali jika menjual hasil produksi, seyogyanya melakukan sortasi dan grading sehingga memberikan nilai tambah yang sekaligus dapat meningkatkan pendapatan.

\section{DAFTAR PUSTAKA}

Adawiyah, R. 2017. Strategi Bunga Sedap Malam (Polianthes Tuberosa) dalam Menghadapi Pasar di Desa Pekoren Kecamatan Rembang Kabupaten Pasuruan. Departemen Antropologi, Fisip Universitas Airlangga.AntroUnairdotNet, Vol.VI/ (2). Hal. 199-212.

Andri, KB. 2013. Analisis Rantai Pasok dan Rantai Nilai Bunga Krisan Di Daerah Sentra Pengembangan Jawa Timur. Vol. 10 (1) Hal.1 - 10.

Anonim, 2014. Laporan Kinerja Direktorat Jenderal Hortikultura. Kementerian Pertanian Republik Indoesia.

Ayesha,I. 2016. Analisis Rantai Pasokan Komoditas Florikultura sebagai Upaya Peningkatan Ekonomi Masyarakat di Kabupaten Bandung Barat. Vol.1 (2). Hal. 133-138.

Badan Pusat Statistik Provinsi Bali ,2012-2017 Bali Dalam Angka : Denpasar.

Heizer. J dan Render. B. 2005, Buku 2 Manajemen Operasi Edisi ketujuh : Salemba Empat. Jakarta.

Indrajit. R.E dan Djokopranoto.R. 2002. Konsep Manajemen Supply Chain : Strategi Mengelola Manajemen Rantai Pasokan Bagi Perusahaan Modern di Indonesia. PT. Gramedia Widiasarana. Jakarta.

Mubarok, S, Nursuhud, Suminar, E,Venny Revia Viola,VR. 2018. Penghambatan Respons Etilen pada Mawar Potong Melalui Modifikasi Larutan Perendam, 1-MCP, dan Sitokinin. Jurnal Ilmu Pertanian Indonesia 
(JIPI), Vol. $23 \quad$ (1): $\quad$ Hal.60 $\square 66$ http://journal.ipb.ac.id/index.php.

Pujawan, I Nyoman. 2005. Supply Chain Management Edisi Pertama. Guna Widya. Surabaya.

Puspasari, ED Rosihan Asmara, Riana, FD. 2017. Analisis Efisiensi Pemasaran Bunga Mawar Potong (Studi Kasus di Desa Gunungsari, Kecamatan Bumiaji, Kota Batu) Jurnal Ekonomi Pertanian dan Agribisnis (JEPA) EVol. I No 2.Hal. 80-93.

Rekarti, E dan Nurhayati, M. 2016. Analisis Structure Conduct Performance (SCP) Jika Terjadi Merger Bank Pembangunan Daerah Dan Bank Bumn Persero Berdasarkan Nilai Aset Dan Nilai Dana. Jurnal Ilmiah Manajemen dan Bisnis. Vol.2. No. 1. Hal. 36-50.

Sari, IRM. 2017 Rantai Pasok Sayuran di PT Bimandiri Agro Sedaya. MIX: Jurnal Ilmiah Manajemen, Volume VII.(3). Hal. 1-87.

Ridhawardani, A, Pardian, P dan Mukti, GW. 2017. Analisis Efisiensi Pemasaran Bunga Mawar Potong di Desa Kertawangi, Kecamatan Cisarua Kabupaten Bandung Barat. Jurnal Agrosains dan Teknologi, Vol. 2 (1). Hal 1321.

Simchi-Levi D, Kaminsky P dan Simchi-Levi E. 2008. Designing and Managing The Supply Chain Concepts. Strategies and Case Studies. New York (USA): Me Graw Hill3rd ed.New York.

Sinaga, SS, Diana Chalil,D dan Emalisa, 2015. Analisis Strategi Pemasaran Bunga Potong (Studi Kasus : Desa Raya Kecamatan Berastagi Kabupaten Karo Provinsi Sumatera Utara) Journal of Agriculture and Agribusiness Socioeconomics. Vol. 4 No.8.Hal.1-13.

Susrusa, KB, 2018. Managemen Pamasaran Pertanian (Bahan Ajar). Program Magister Agribisnis, Universitas Udayana : Denpasar. 